\title{
UPAYA MENINGKATKAN KETERAMPILAN DAN MOTIVASI MEMBACA GEGURITAN MELALUI METODE TEATRIKALISASI GEGURITAN PADA PESERTA DIDIK KELAS 6 SD 1 SADANG KECAMATAN JEKULO KABUPATEN KUDUS SEMESTER 1 TAHUN PELAJARAN 2014/2015
}

\author{
ABSTRAK \\ Kusniati*) \\ kusniyatispd60@gmail.com
}

Tujuan yang hendak dicapai adalah untuk meningkatkan: (1) keterampilan membaca geguritan, yaitu aktualisasi teknik meliputi nada, tempo, dinamik, dan ekspresi dalam membaca geguritan; dan (2) motivasi peserta didik dalam pembelajaran, yaitu keaktifan, ketertarikan, keinginan peserta didik untuk belajar membaca geguritan sesuai dengan teknik membaca geguritan dengan benar.

Penelitian ini merupakan penelitian tindakan kelas (PTK) yang dilakukan di SD 1 Sadang Kecamatan Jekulo Kabupaten Kudus, dengan subjek para peserta didik kelas 6 semester 1 tahun pelajaran 2014/2015. Jumlah peserta didik ada 32, dengan rincian 16 lakilaki dan 16 perempuan. Adapun yang menjadi objek penelitian adalah pembelajaran membaca geguritan. Proses penelitian dilaksanakan dalam dua siklus yang meliputi empat tahapan, yaitu tahap perencanaan, tahap pelaksanaan, tahap observasi, serta tahap analisis dan refleksi.

Berdasarkan hasil penelitian dapat disimpulkan terdapat peningkatan kualitas pembelajaran baik proses maupun hasil membaca geguritan pada peserta didik kelas 6 semester 1 tahun pelajaran 2014/2015. Peningkatan kualitas proses pembelajaran tersebut ditandai dengan meningkatnya: (1) jumlah kualitas peserta didik yang aktif dalam kegiatan apersepsi maupun dalam kegiatan pembelajaran; (2) jumlah peserta didik yang tertarik dan termotivasi dalam kegiatan pembelajaran membaca geguritan; dan (3) jumlah peserta didik yang sudah mampu membaca geguritan dengan teknik yang benar dengan menggunakan metode teatrikalisasi geguritan. Adapun peningkatan kualitas hasil pembelajaran ditandai dengan meningkatnya jumlah peserta didik yang mencapai batas ketuntasan, yaitu pada siklus 1 adalah 21 peserta didik dari 32 peserta didik (66\%). Pada siklus 2 menjadi 30 peserta didik (94\%). Adapun langkah-langkah efektif yang dilakukan oleh peneliti untuk mengoptimalkan metode ini, antara lain: (1) membagi peserta didik secara berkelompok yang didasarkan perbedaan tingkat kemampuan membaca geguritan; (2) memberi kesempatan kepada peserta didik untuk berlatih membaca geguritan melalui metode teatrikalisasi geguritan; (3) mengintegrasikan keterampilan membaca geguritan dengan keterampilan berbahasa lainnya, seperti berbicara, membaca, dan mendengarkan; dan (4) mengaplikasikan membaca geguritan dalam kegiatan seni di lingkungan sekolah khususnya sesuai pengalaman yang didapat peserta didik selama penelitian. Prinsip pokok pada metode ini adalah mengetahui, berlatih, menerapkan, memeragakan, sehingga peserta didik mengaktualisasikan nada, tempo, dinamik,ekspresi, dalam membaca geguritan dengan benar.

Kata Kunci: "Membaca geguritan", 'Tetrikalisasi geguritan". 


\section{HOW TO IMPROVE SKILLS AND MOTIVATION THROUGH READING METHOD GEGURITAN TEATRIKALISASI OF JAVA POETRY STUDENTS IN CLASS 6 SD 1 SADANG JEKULO DISTRICT KUDUS OF LESSONS $1^{\text {st }}$ SEMESTER YEAR 2014/2015}

The Aimed is to increase: (1) reading skills geguritan, namely actualization techniques include tone, tempo, dynamics, and expression in reading geguritan; and (2) the motivation of learners in the learning, that liveliness, interest, desire of students to learn to read geguritan accordance with the techniques geguritan correctly.

This research is a classroom action research (CAR) conducted in SD 1 Sadang Jekulo District of Kudus, with the subject of Grade 6 learners first half of the school year 2014/2015. Number of students, there are 32, with details of 16 men and 16 women. As for who becomes the object of research is learning to read geguritan. The research process was conducted in two cycles which include four stages, namely the planning phase, the implementation phase, the stage of observation, as well as the stage of analysis and reflection.

Based on the results of this study concluded there is an increase in the quality of learning both the process and the results read geguritan in grade 6 learners first half of the school year 2014/2015. Improving the quality of the learning process is characterized by increasing: (1) the number of quality students who are active in apersepsi activities and in learning activities; (2) the number of learners who are interested and motivated in learning to read geguritan; and (3) the number of learners who are able to read geguritan with the correct technique using geguritan teatrikalisasi. As for improving the quality of learning outcomes characterized by an increasing number of students who reach the limit of completeness, that in cycle 1 was 21 learners from 32 students (66\%). In cycle 2 to 30 learners (94\%). As effective measures undertaken by the researchers to optimize these methods, among others: (1) divides the learners in groups based differences in literacy levels geguritan; (2) provide opportunities for learners to practice reading through methods teatrikalisasi geguritan; (3) integrate reading skills geguritan with other language skills such as speaking, reading, and listening; and (4) apply read geguritan in art activities in the school environment is particularly suitable learners experience gained during the study. Fundamental principle of this method is to know, to practice, apply, demonstrate, so that learners actualize the tone, tempo, dynamics, expression, reading geguritan correctly.

Keyword: "Reading geguritan", "Teatrikalisasi geguritan". 


\section{PENDAHULUAN}

Pembelajaran membaca geguritan merupakan pembelajaran yang sulit dan kurang disukai oleh siswa. Kenyataan ini didukung dengan perolehan nilai siswa yang cenderung rendah ditambah motivasi belajar yang rendah pula. Dari hasil ulangan harian 32 siswa, hanya 2 siswa atau 5,2 \% yang mendapat nilai amat baik, 6 siswa atau 15,8\% siswa mendapatkan nilai baik, 30 siswa atau $79 \%$ cukup/kurang. Selama proses pembelajaran membaca geguritan pun siswa terlihat lesu, tidak bergairah, merasa bosan, dan bahkan merasa tidak percaya diri.

Selama ini, proses pembelajaran membaca geguritan yang disampaikan guru di kelas, masih bersifat konvensional dengan mengandalkan metode membaca yang biasa tanpa disertai dengan gerakan-gerakan yang bersifat motorik untuk lebih menarik perkatian siswa dan lebih memperjelas makna atau isi dari geguritan yang dibaca itu sendiri dengan bantuan gerakan, mimik, ataupun ekspresi wajah lain yang merupakan penggambaran setiap kalimat dalam geguritan. Proses ini hanya menekankan pada pencapaian tuntutan kurikulum dan penyampaian tekstual semata. Akibatnya, motivasi dan kompetensi yang didapat tidak seperti yang diharapkan.

Dalam konsep CTL yang mengembangkan pembelajaran PAIKEM, aktivitas siswa akan lebih meningkat, ditambah proses pembelajaran dengan multi metode pembelajaran yang bervariasi, lebih menitikberatkan peran serta siswa dalam kegiatan belajar, yakni siswa berupaya mencapai tujuan dengan mendapatkan pengalaman langsung dalam membaca geguritan dengan memahami berbagai bentuk gerakan atau ekspresi mimik dalam membaca geguritan. Dengan memperhatikan gerak gerik motorik ataupun ekspresi penjiwaan dalam pembacaan geguritan, siswa dapat tertarik dan menemukan sendiri isi geguritan yang dibaca. Dengan demikian, ketercapaian tujuan pembelajaran membaca geguritan akan maksimal.

Pembelajaran membaca geguritan dengan menitikberatkan pada pemahaman berbagai bentuk gerakan atau ekspresi mimik dalam membaca geguritan akan menjadikan pembelajaran berlangsung lebih menarik, menyenangkan, kompetitif, dan bersifat apresiatif. Keantusiasan peserta didik dalam pembelajaran membaca geguritan secara totalitas akan tampak dalam pembelajaran ini. Guru di sini berperan sebagai fasilitator dan manajemen pembelajaran.

Harapan seperti di atas tidak ditemui peneliti pada siswa kelas 6 SD 1 Sadang Kecamatan Jekulo Kabupaten Kudus Semester 1 Tahun 2014/2015. Kenyataan yang ada jauh dari harapan dan tuntutan dalam kurikulum. Hal ini disebabkan oleh rendahnya kemampuan siswa dalam membaca geguritan serta kurangnya pemahaman siswa tentang isi geguritan yang dibacanya sendiri. Selain itu, metode pembelajaran yang kurang bervariasi ditambah dengan media pembelajaran yang monoton, menjadikan pembelajaran bahasa Jawa khususnya membaca geguritan sangat tidak disukai siswa. Hal ini tentunya menjadi masalah dalam proses pembelajaran.

Namun penulis mempunyai keyakinan, apabila guru mampu mengaplikasikan multi metode yang bervariasi, menarik, tepat dengan tujuan, tidak membosankan, ditambah dengan penggunaan multi media yang bervariasi dalam pembelajaran, maka tujuan pembelajaran membaca geguritan akan dapat tercapai.

Dalam penelitian ini, hanya berfokus pada keterampilan membaca geguritan dengan metode teatrikalisasi geguritan pada peserta didik kelas 6 Semester 1Tahun Pelajaran 2014/2015 SD 1 Sadang Kecamatan Jekulo Kabupaten Kudus.

Berdasarkan latar belakang dan identifikasi masalah di atas, maka dapat dirumuskan beberapa masalah sebagai berikut: 1) bagaimanakah proses pembelajaran membaca geguritan dengan menggunakan metode teatrikalisasi geguritan peserta didik kelas 6 Semester 1Tahun Pelajaran 2014/2015 SD 1 Sadang Kecamatan Jekulo Kabupaten Kudus; 2) seberapa banyak peningkatan keterampilan dan motivasi membaca geguritan dengan menggunakan metode teatrikalisasi geguritan peserta didik kelas 6 Semester 1Tahun Pelajaran 2014/2015 SD 1 Sadang Jekulo Kudus; 3) bagaimanakah 
perubahan perilaku/motivasi peserta didik dalam pembelajaran membaca geguritan dengan menggunakan metode teatrikalisasi geguritan peserta peserta didik kelas 6 Semester 1Tahun Pelajaran 2014/2015 SD 1 Sadang Kecamatan Jekulo Kabupaten Kudus? Sesuai dengan rumusan masalah yang telah ditetapkan, penelitian ini dilakukan dengan tujuan untuk meningkatkan keterampilan membaca geguritan peserta didik kelas 6 Semester 1Tahun Pelajaran 2014/2015 SD 1 Sadang Kecamatan Jekulo Kabupaten Kudus melalui penggunaan metode teatrikalisasi geguritan dalam kegiatan pembelajaran. Secara khusus, penelitian ini bertujuan sebagai berikut: 1) mendeskripsi proses pembelajaran membaca geguritan dengan menggunakan metode teatrikalisasi geguritan peserta didik kelas 6 Semester 1Tahun Pelajaran 2014/2015 SD 1 Sadang Kecamatan Jekulo Kabupaten Kudus, 2) mendeskripsi peningkatan keterampilan dan motivasi membaca geguritan dengan menggunakan metode teatrikalisasi geguritan peserta didik kelas 6 Semester 1Tahun Pelajaran 2014/2015 SD 1 Sadang Kecamatan Jekulo Kabupaten Kudus, 3) mengidentifikasi perubahan perilaku peserta didik dalam pembelajaran membaca geguritan dengan menggunakan metode teatrikalisasi geguritan peserta didik kelas 6 Semester 1Tahun Pelajaran 2014/2015 SD 1 Sadang Kecamatan Jekulo Kabupaten Kudus.

Hasil penelitian ini diharapkan dapat menambah khasanah ilmu pengetahuan yang terkait dengan proses pembelajaran untuk mengembangkan kemampuan keterampilan membaca geguritan pada peserta didik kelas 6 Semester 1Tahun Pelajaran 2014/2015 SD Negeri 1 Sadang Kecamatan Jekulo Kabupaten Kudus dengan metode teatrikalisasi geguritan.

\section{LANDASAN TEORETIS DAN HIPOTESIS TINDAKAN}

Keterampilan adalah kecakapan untuk menyelesaikan tugas.Pembelajaran bahasa sekarang sudah saatnya menitikberatkan pada keterampilan bahasa (Depdiknas 2003:13). Selanjutnya sesuai dengan Keputusan Gubernur Jawa Tengah nomor 423.5/5/2010 Tentang Kurikulum Muatan Lokal Bahasa
Jawa telah menggariskan bahwa ada empat keterampilan berbahasa Jawa yang menjadi Standar Kompetensi, yaitu mendengarkan (nyemak), keterampilan berbicara (wicara), keterampilan membaca (maca), dan keterampilan menulis (nulis).

Hodgson (dalam Tarigan 1987 : 7) berpendapat bahwa membaca adalah suatu proses yang dilakukan serta dipergunakan untuk memperoleh pesan, yang hendak disampaikan oleh penulis melalui media katakata atau bahasa tulis. Suatu proses yang menuntut agar kelompok kata yang merupakan suatu kesatuan akan terlihat dalam suatu pandangan sekilas, dan agar makna kata-kata secara individual akan dapat diketahui. Kalau hal ini tidak terpenuhi, maka pesan yang tersurat dan yang tersirat tidak akan tertangkap atau dipahami, dan proses membaca itu tidak terlaksana dengan baik.

Dari segi linguistik Anderson (dalam Tarigan 1987 : 7) berpendapat membaca adalah suatu proses penyandian kembali dan pembacaan sandi, berlainan dengan berbicara dan menulis yang justru melibatkan penyandian. Sebuah aspek pembacaan sandi adalah menghubungkan kata-kata tulis dengan makna bahasa lisan yang mencakup pengubahan tulisan menjadi bunyi yang bermakna.

Geguritan atau puisi merupakan wacana sastra yang menggunakan bahasa padat, pekat, dan memiliki makna (dalam tradisi jawa ada suatu istilah khas untuk menamai puisi dengan penekanan pada aspek kebahasaan, yakni bahasa pinathok "bahasa yang terpatok"). Disini juga dijelaskan bahwa geguritan merupakan cipta sastra terbaru yang hidup hingga saat ini menggunakan bahasa jawa "masa kini" serta tidak memiliki kebakuan puitik yang ketat sehingga pemahamannya dianggap lebih mudah dibanding jenis-jenis puisi jawa yang lain (Saputra, 2001: 2).

Geguritan adalah sebutan puisi yang menggunakan bahasa Jawa. Geguritan berasal dari kata dasar gurit yang berarti : kidung atau tulisan yang berujud tatahan.

Geguritan dibagi menjadi dua, yaitu :

1. Geguritan Gagrag Lawas (tradisional)

- Terdiri dari 4 baris/ 6 baris/ 8 baris 
- Jumlah suku kata pada setiap baris

sama

- Jatuhnya suara pada setiap akhir kalimat sama

- Selalu dimulai dengan kata " sun nggurit "

\section{Geguritan Gagrag Anyar}

Geguritan gagrag anyar juga disebut puisi jawa modern, tidak terikat dengan aturanaturan yang ada dalam geguritan tradisional (gagrag lawas)

Geguritan gagrag anyar lebih mengutamakan :

1. Pilihan kata yang berisi ( Diksi )

2. Gaya bahasa (Purwakanthi, Dwipurwa, Dwiwasana, seselan, lsp.)

3. Irama .

Memeragakan geguritan yang berhubungan dengan unsur-unsur dalam membaca geguritan merupakan salah satu seni pertunjukan. Latihan dapat dilakukan proses ketika pembaca geguritan menghadapi naskah geguritan. Latihan bertujuan untuk mencari isi dan bagaimana mengutarakan isi tersebut kepada orang lain.

Gaya dalam mengungkapkan kebahasaan dalam geguritan dikreasikan lagi. Pemilihan bentuk bahasa dapat menghasilkan efek keindahan tersebut. Pemilihan gaya bahasa mendukung terbentuknya isi, dan yang membaca harus dapat mengungkapkan. Dan yang terpenting harus diperhatikan bahwa pembaca geguritan bukanlah pengganti pengarang.

Bab-bab yang dapat dilakukan dalam menafsirkan dan membaca geguritan seperti yang diungkapkan oleh Sendang Mulyono dalam "Menafsirkan dan Membaca Geguritan " (2009: 7) seperti di bawah ini.

1. Mencari makna denotatif

2. Mencari makna konotatif

3. Membuat asosiasi

4. Berlatih membaca geguritan

5. Membaca geguritan dengan vocal, penghayatan, lan penampilan yang baik.

Dalam menafsirkan geguritan tentu saja dimulai dari tema, swasana, isi yang termuat dalam geguritan dan apa saja yang dapat membuat pembaca geguritan dapat memahami isi geguritan seutuhnya.

Membaca geguritan, atau yang sering disebut poetry reading, bukan sesuatu yang baru dalam perkembangan sastra Jawa. Sejak tahun 1950-an, kegiatan membaca geguritan tersebut sering dinamakan deklamasi, sudah diketahui secara luas oleh semua peserta didik.

Suwignyo (2005), dalam (http://endonesa.wordpress.com/lenterasastra/membaca-puisi/) mengemukakan bahwa bentuk dan gaya baca puisi dapat dibedakan mejadi tiga, yaitu (1) bentuk dan gaya baca puisi secara poetry reading, (2) bentuk dan gaya baca puisi secara deklamatoris, dan (3) bentuk dan gaya baca puisi secara teaterikal.

Ciri khas dari bentuk dan gaya baca puisi poerty reading adalah diperkenankannya pembaca membawa teks puisi. Adapaun posisi dalam bentuk dan gaya baca puisi ini dapat dilakukan dengan (1) berdiri, (2) duduk, dan (3) berdiri, duduk, dan bergerak.

Jika pembaca memilih bentuk dan gaya baca dengan posisi berdiri, maka pesan puisi disampaikan melalui gerakan badan, kepala, wajah, dan tangan. Intonasi baca seperti keras lemah, cepat lambat, tinggi rendah dilakukan dengan cara sederhana. Bentuk dan gaya baca puisi ini relatif mudah dilakukan.

Jika pembaca memilih bentuk dan gaya baca dengan posisi duduk, maka pesan puisi disampaikan melalui (1) gerakangerakan kepala: mengenadah, menunduk menoleh, (2) gerakan raut wajah: mengerutkan dahi, mengangkat alis, (3) gerakan mata: membelakak, meredup, memejam, (4) gerakan bibir: tersenyum, mengatup, melongo, dan (5) gerakan tangan, bahu, dan badan, dilakukan seperlunya. Sedangkan intonasi baca dilakukan dengan cara (1) membaca dengan keras kata-kata tertentu, (2) membaca dengan lambat katakata tertentu, dan (3) membaca dengan nada tinggi kata-kata tertentu.

Jika pembaca memilih bentuk dan gaya baca puisi duduk, berdiri, dan bergerak, maka yang harus dilakukan pada posisi duduk adalah (1) memilih sikap duduk dengan santai, (2) arah dan pandangan mata dilakukan secara bervariasi, dan (3) melakukan gerakan tangan dilakuakan dengan seperlunya. Sedang yang dilakukan pada saat berdiri adalah (1) mengambil sikap santai, (2) gerakan tangan, gerakan bahu, dan posisi 
berdiri dilakukan dengan bebas, dan (3) ekspresi wajah: kerutan dahi, gerakan mata, senyuman dilakukan dengan wajar. Yang dilakukan pada saat bergerak adalah (1) melakukan dengan tenang dan terkendali, dan (2) menghindari gerakan-gerakan yang berlebihan. Intonasi baca dilakukan dengan cara (1) membaca dengan keras kata-kata tertentu, (2) membaca dengan lambat katakata tertentu, dan (3) membaca dengan nada tinggi kata-kata tertentu.

Ciri khas dari bentuk dan gaya baca puisi seacra deklamatoris adalah lepasnya teks puisi dari pembaca. Jadi, sebelum mendeklamasikan puisi, teks puisi harus dihapalkan. Bentuk dan gaya baca puisi ini dapat dilakukan dengan posisi (1) berdiri, (2) duduk, dan (3) berdiri, duduk, dan bergerak.

Jika deklamator memilih bentuk dan gaya baca dengan posisi berdiri, maka pesan puisi disampaikan melalui (1) gerakangerakan tangan: mengepal, menunjuk, mengangkat kedua tangan, (2) gerakangerakan kepala: melihat ke bawah, atas, samping kanan, samping kiri, serong, (3) gerakan-gerakan mata: membelalak, meredup, memejam, (4) gerakan-gerakan bibir: tersenyumm, mengatup, melongo, (5) gerakan-gerakan tangan, bahu, badan, dan raut muka dilakukan dengan total. Intonasi baca dilakukan dengan cara (1) membaca dengan keras kata-kata tertentu, (2) membaca dengan lambat kata-kata tertentu, (3) membaca dengan nada tinggi kata-kata tertentu.

Jika deklamator memilih bentuk dan gaya dengan posisi duduk, berdiri, dan bergerak, maka yang dilakukan pada posisi duduk adalah (1) memilih posisi duduk dengan santai, kaki agak ditekuk, posisi miring dan badan agak membungkuk, Dan (2) arah dan pandangan mata dilakukan bervariasi: menatap dan menunduk. Sedang yang dilakukan pada posisi berdiri (1) mengambil sikap tegak dengan wajah menengadah, tangan menunjuk, dan (2) wajah berseri-seri dan bibir tersenyum. Yang dilakukan pada saat bergerak (1) melakukan dengan tenang dan bertenaga, dan (2) kaki dilangkahkan dengan pelan dan tidak tergesagesa. Intonasi dilakukan dengan cara (1) membaca dengan keras kata-kata tertentu, (2) membaca dengan lambat kata-kata tertentu, dan (3) membaca dengan nada tinggi katakata tertentu.

Ciri khas bentuk dan gaya baca puisi teaterikal bertumpu pada totalitas ekspresi, pemakaian unsur pendukung, misal kostum, properti, setting, musik, dll., meskipun masih terikat oleh teks puisi/tidak. Bentuk dan gaya baca puisi secara teaterikal lebih rumit daripada poetry reading maupun deklamatoris. Puisi yang sederhana apabila dibawakan dengan ekspresi akan sangat memesona.

Senada dengan hal tersebut, menurut Raminah Baribin dalam Suliyanto (2009:910) bahwa cara membaca untuk mengapresiasi puisi (geguritan) diantaranya dapat dilakukan dengan cara Exhibition Teaching Learning, dimana dalam pembelajaran peserta didik diharapkan tampil (exhibition) dan adu keterampilan/kompetisi (champion).

Wujud dari penampilan (exhibition) tersebut di antaranya dapat diaktualisasikan dengan gaya baca teatrikal. Teatrikalisasi mampunyai makna pementasan suatu karya yang mengutamakan gerak-gerik, suara, tidak berunsur cerita yang bersifat alur, tetapi memperlihatkan nuansa suasana yang mengarah kepada suatu gambaran samar yang dapat diberi makna oleh penonton.

Bertolak dari penjelasan di atas, maka metode teatrikalisasi dapat dipergunakan untuk mendorong peserta didik agar dapat menyelidiki membaca geguritan dengan mengaktualisasikan bahasa puisi dalam gerakan-gerakan pentas. Metode ini identik dengan pendekatan laboratoris dan belajar bebas.

Membaca geguritan dengan metode teatrikalisasi adalah cara membaca geguritan dengan mengaktualisasikan bahasa puisi dalam gerakan-gerakan pentas. Aktualisasi tersebut dengan memperhatikan isi, tempo, nada, dinamik, ekspresi dalam geguritan.

Motivasi menurut Anton M. Moeliono (2000:756) adalah dorongan yang timbul pada diri seseorang secara sadar atau tidak sadar untuk melakukan tindakan dengan tujuan tertentu. Motivasi membaca geguritan adalah dorongan yang timbul pada diri peserta 
didik untuk membaca geguritan dengan teknik dan pemahaman yang benar.

Berdasarkan kerangka berpikir tersebut, peneliti berasumsi bahwa: 1) pemanfaatan metode pembelajaran teatrikalisasi geguritan untuk aspek membaca geguritan diduga meningkatkan aktivitas belajar peserta didik, 2) metode pembelajaran teatrikalisasi geguritan diduga efektif untuk merubah motivasi belajar peserta dalam pembelajaran membaca geguritan, dan 3) pemanfaatan metode teatrikalisasi geguritan diduga efektif meningkatkan keterampilan membaca geguritan peserta didik Kelas 6 SD 1 Sadang Kecamatan Jekulo Kabupaten Kudus semester 1 tahun pelajaran 2014/1015.

\section{PENDAHULUAN}

Pembelajaran membaca geguritan merupakan pembelajaran yang sulit dan kurang disukai oleh siswa. Kenyataan ini didukung dengan perolehan nilai siswa yang cenderung rendah ditambah motivasi belajar yang rendah pula. Dari hasil ulangan harian 32 siswa, hanya 2 siswa atau 5,2\% yang mendapat nilai amat baik, 6 siswa atau 15,8 \% siswa mendapatkan nilai baik, 30 siswa atau $79 \%$ cukup/kurang. Selama proses pembelajaran membaca geguritan pun siswa terlihat lesu, tidak bergairah, merasa bosan, dan bahkan merasa tidak percaya diri.

Selama ini, proses pembelajaran membaca geguritan yang disampaikan guru di kelas, masih bersifat konvensional dengan mengandalkan metode membaca yang biasa tanpa disertai dengan gerakan-gerakan yang bersifat motorik untuk lebih menarik perkatian siswa dan lebih memperjelas makna atau isi dari geguritan yang dibaca itu sendiri dengan bantuan gerakan, mimik,ataupun ekspresi wajah lain yang merupakan penggambaran setiap kalimat dalam geguritan. Proses ini hanya menekankan pada pencapaian tuntutan kurikulum dan penyampaian tekstual semata. Akibatnya, motivasi dan kompetensi yang didapat tidak seperti yang diharapkan.

Dalam konsep CTL yang mengembangkan pembelajaran PAIKEM, aktivitas siswa akan lebih meningkat, ditambah proses pembelajaran dengan multi metode pembelajaran yang bervariasi, lebih menitikberatkan peran serta siswa dalam kegiatan belajar, yakni siswa berupaya mencapai tujuan dengan mendapatkan pengalaman langsung dalam membaca geguritan dengan memahami berbagai bentuk gerakan atau ekspresi mimik dalam membaca geguritan. Dengan memperhatikan gerak gerik motorik ataupun ekspresi penjiwaan dalam pembacaan geguritan, siswa dapat tertarik dan menemukan sendiri isi geguritan yang dibaca. Dengan demikian, ketercapaian tujuan pembelajaran membaca geguritan akan maksimal.

Pembelajaran membaca geguritan dengan menitikberatkan pada pemahaman berbagai bentuk gerakan atau ekspresi mimik dalam membaca geguritan akan menjadikan pembelajaran berlangsung lebih menarik, menyenangkan, kompetitif, dan bersifat apresiatif. Keantusiasan peserta didik dalam pembelajaran membaca geguritan secara totalitas akan tampak dalam pembelajaran ini. Guru di sini berperan sebagai fasilitator dan manajemen pembelajaran.

Harapan seperti di atas tidak ditemui peneliti pada siswa kelas 6 SD 1 Sadang Kecamatan Jekulo Kabupaten Kudus Semester 1 Tahun 2014/2015. Kenyataan yang ada jauh dari harapan dan tuntutan dalam kurikulum. Hal ini disebabkan oleh rendahnya kemampuan siswa dalam membaca geguritan serta kurangnya pemahaman siswa tentang isi geguritan yang dibacanya sendiri. Selain itu, metode pembelajaran yang kurang bervariasi ditambah dengan media pembelajaran yang monoton, menjadikan pembelajaran bahasa Jawa khususnya membaca geguritan sangat tidak disukai siswa. Hal ini tentunya menjadi masalah dalam proses pembelajaran.

Namun penulis mempunyai keyakinan, apabila guru mampu mengaplikasikan multi metode yang bervariasi, menarik, tepat dengan tujuan, tidak membosankan, ditambah dengan penggunaan multi media yang bervariasi dalam pembelajaran, maka tujuan pembelajaran membaca geguritan akan dapat tercapai.

Dalam penelitian ini, hanya berfokus pada keterampilan membaca geguritan dengan metode teatrikalisasi geguritan pada 
peserta didik kelas 6 Semester 1Tahun Pelajaran 2014/2015 SD 1 Sadang Kecamatan Jekulo Kabupaten Kudus.

Berdasarkan latar belakang dan identifikasi masalah di atas, maka dapat dirumuskan beberapa masalah sebagai berikut: 1) bagaimanakah proses pembelajaran membaca geguritan dengan menggunakan metode teatrikalisasi geguritan peserta didik kelas 6 Semester 1Tahun Pelajaran 2014/2015 SD 1 Sadang Kecamatan Jekulo Kabupaten Kudus; 2) seberapa banyak peningkatan keterampilan dan motivasi membaca geguritan dengan menggunakan metode teatrikalisasi geguritan peserta didik kelas 6 Semester 1Tahun Pelajaran 2014/2015 SD 1 Sadang Jekulo Kudus; 3) bagaimanakah perubahan perilaku/motivasi peserta didik dalam pembelajaran membaca geguritan dengan menggunakan metode teatrikalisasi geguritan peserta peserta didik kelas 6 Semester 1Tahun Pelajaran 2014/2015 SD 1 Sadang Kecamatan Jekulo Kabupaten Kudus? Sesuai dengan rumusan masalah yang telah ditetapkan, penelitian ini dilakukan dengan tujuan untuk meningkatkan keterampilan membaca geguritan peserta didik kelas 6 Semester 1Tahun Pelajaran 2014/2015 SD 1 Sadang Kecamatan Jekulo Kabupaten Kudus melalui penggunaan metode teatrikalisasi geguritan dalam kegiatan pembelajaran. Secara khusus, penelitian ini bertujuan sebagai berikut: 1) mendeskripsi proses pembelajaran membaca geguritan dengan menggunakan metode teatrikalisasi geguritan peserta didik kelas 6 Semester 1Tahun Pelajaran 2014/2015 SD 1 Sadang Kecamatan Jekulo Kabupaten Kudus, 2) mendeskripsi peningkatan keterampilan dan motivasi membaca geguritan dengan menggunakan metode teatrikalisasi geguritan peserta didik kelas 6 Semester 1Tahun Pelajaran 2014/2015 SD 1 Sadang Kecamatan Jekulo Kabupaten Kudus, 3) mengidentifikasi perubahan perilaku peserta didik dalam pembelajaran membaca geguritan dengan menggunakan metode teatrikalisasi geguritan peserta didik kelas 6 Semester 1Tahun Pelajaran 2014/2015 SD 1 Sadang Kecamatan Jekulo Kabupaten Kudus.

Hasil penelitian ini diharapkan dapat menambah khasanah ilmu pengetahuan yang terkait dengan proses pembelajaran untuk mengembangkan kemampuan keterampilan membaca geguritan pada peserta didik kelas 6 Semester 1Tahun Pelajaran 2014/2015 SD Negeri 1 Sadang Kecamatan Jekulo Kabupaten Kudus dengan metode teatrikalisasi geguritan.

\section{LANDASAN TEORETIS DAN HIPOTESIS TINDAKAN}

Keterampilan adalah kecakapan untuk menyelesaikan tugas.Pembelajaran bahasa sekarang sudah saatnya menitikberatkan pada keterampilan bahasa (Depdiknas 2003:13). Selanjutnya sesuai dengan Keputusan Gubernur Jawa Tengah nomor 423.5/5/2010 Tentang Kurikulum Muatan Lokal Bahasa Jawa telah menggariskan bahwa ada empat keterampilan berbahasa Jawa yang menjadi Standar Kompetensi, yaitu mendengarkan (nyemak), keterampilan berbicara (wicara), keterampilan membaca (maca), dan keterampilan menulis (nulis).

Hodgson (dalam Tarigan 1987 : 7) berpendapat bahwa membaca adalah suatu proses yang dilakukan serta dipergunakan untuk memperoleh pesan, yang hendak disampaikan oleh penulis melalui media katakata atau bahasa tulis. Suatu proses yang menuntut agar kelompok kata yang merupakan suatu kesatuan akan terlihat dalam suatu pandangan sekilas, dan agar makna kata-kata secara individual akan dapat diketahui. Kalau hal ini tidak terpenuhi, maka pesan yang tersurat dan yang tersirat tidak akan tertangkap atau dipahami, dan proses membaca itu tidak terlaksana dengan baik.

Dari segi linguistik Anderson (dalam Tarigan 1987 : 7) berpendapat membaca adalah suatu proses penyandian kembali dan pembacaan sandi, berlainan dengan berbicara dan menulis yang justru melibatkan penyandian. Sebuah aspek pembacaan sandi adalah menghubungkan kata-kata tulis dengan makna bahasa lisan yang mencakup pengubahan tulisan menjadi bunyi yang bermakna.

Geguritan atau puisi merupakan wacana sastra yang menggunakan bahasa padat, pekat, dan memiliki makna (dalam tradisi jawa ada suatu istilah khas untuk menamai puisi dengan penekanan pada aspek 
kebahasaan, yakni bahasa pinathok "bahasa yang terpatok"). Disini juga dijelaskan bahwa geguritan merupakan cipta sastra terbaru yang hidup hingga saat ini menggunakan bahasa jawa "masa kini" serta tidak memiliki kebakuan puitik yang ketat sehingga pemahamannya dianggap lebih mudah dibanding jenis-jenis puisi jawa yang lain (Saputra, 2001: 2).

Geguritan adalah sebutan puisi yang menggunakan bahasa Jawa. Geguritan berasal dari kata dasar gurit yang berarti : kidung atau tulisan yang berujud tatahan.

Geguritan dibagi menjadi dua, yaitu :

1. Geguritan Gagrag Lawas (tradisional)

- Terdiri dari 4 baris/ 6 baris/ 8 baris

- Jumlah suku kata pada setiap baris

sama

kalimat sama

- Jatuhnya suara pada setiap akhir nggurit "

- Selalu dimulai dengan kata " sun

\section{Geguritan Gagrag Anyar}

Geguritan gagrag anyar juga disebut puisi jawa modern, tidak terikat dengan aturanaturan yang ada dalam geguritan tradisional (gagrag lawas)

Geguritan gagrag anyar lebih mengutamakan :

4. Pilihan kata yang berisi (Diksi)

5. Gaya bahasa (Purwakanthi, Dwipurwa, Dwiwasana, seselan, lsp.)

6. Irama .

Memeragakan geguritan yang berhubungan dengan unsur-unsur dalam membaca geguritan merupakan salah satu seni pertunjukan. Latihan dapat dilakukan proses ketika pembaca geguritan menghadapi naskah geguritan. Latihan bertujuan untuk mencari isi dan bagaimana mengutarakan isi tersebut kepada orang lain.

Gaya dalam mengungkapkan kebahasaan dalam geguritan dikreasikan lagi. Pemilihan bentuk bahasa dapat menghasilkan efek keindahan tersebut. Pemilihan gaya bahasa mendukung terbentuknya isi, dan yang membaca harus dapat mengungkapkan. Dan yang terpenting harus diperhatikan bahwa pembaca geguritan bukanlah pengganti pengarang.

Bab-bab yang dapat dilakukan dalam menafsirkan dan membaca geguritan seperti yang diungkapkan oleh Sendang Mulyono dalam "Menafsirkan dan Membaca Geguritan " (2009: 7) seperti di bawah ini.

6. Mencari makna denotatif

7. Mencari makna konotatif

8. Membuat asosiasi

9. Berlatih membaca geguritan

10. Membaca geguritan dengan vocal, penghayatan, lan penampilan yang baik.

Dalam menafsirkan geguritan tentu saja dimulai dari tema, swasana, isi yang termuat dalam geguritan dan apa saja yang dapat membuat pembaca geguritan dapat memahami isi geguritan seutuhnya.

Membaca geguritan, atau yang sering disebut poetry reading, bukan sesuatu yang baru dalam perkembangan sastra Jawa. Sejak tahun 1950-an, kegiatan membaca geguritan tersebut sering dinamakan deklamasi, sudah diketahui secara luas oleh semua peserta didik.

Suwignyo (2005), dalam (http://endonesa.wordpress.com/lenterasastra/membaca-puisi/) mengemukakan bahwa bentuk dan gaya baca puisi dapat dibedakan mejadi tiga, yaitu (1) bentuk dan gaya baca puisi secara poetry reading, (2) bentuk dan gaya baca puisi secara deklamatoris, dan (3) bentuk dan gaya baca puisi secara teaterikal.

Ciri khas dari bentuk dan gaya baca puisi poerty reading adalah diperkenankannya pembaca membawa teks puisi. Adapaun posisi dalam bentuk dan gaya baca puisi ini dapat dilakukan dengan (1) berdiri, (2) duduk, dan (3) berdiri, duduk, dan bergerak.

Jika pembaca memilih bentuk dan gaya baca dengan posisi berdiri, maka pesan puisi disampaikan melalui gerakan badan, kepala, wajah, dan tangan. Intonasi baca seperti keras lemah, cepat lambat, tinggi rendah dilakukan dengan cara sederhana. Bentuk dan gaya baca puisi ini relatif mudah dilakukan.

Jika pembaca memilih bentuk dan gaya baca dengan posisi duduk, maka pesan puisi disampaikan melalui (1) gerakangerakan kepala: mengenadah, menunduk menoleh, (2) gerakan raut wajah: mengerutkan dahi, mengangkat alis, (3) gerakan mata: membelakak, meredup, memejam, (4) gerakan bibir: tersenyum, mengatup, melongo, dan (5) gerakan tangan, 
bahu, dan badan, dilakukan seperlunya. Sedangkan intonasi baca dilakukan dengan cara (1) membaca dengan keras kata-kata tertentu, (2) membaca dengan lambat katakata tertentu, dan (3) membaca dengan nada tinggi kata-kata tertentu.

Jika pembaca memilih bentuk dan gaya baca puisi duduk, berdiri, dan bergerak, maka yang harus dilakukan pada posisi duduk adalah (1) memilih sikap duduk dengan santai, (2) arah dan pandangan mata dilakukan secara bervariasi, dan (3) melakukan gerakan tangan dilakuakan dengan seperlunya. Sedang yang dilakukan pada saat berdiri adalah (1) mengambil sikap santai, (2) gerakan tangan, gerakan bahu, dan posisi berdiri dilakukan dengan bebas, dan (3) ekspresi wajah: kerutan dahi, gerakan mata, senyuman dilakukan dengan wajar. Yang dilakukan pada saat bergerak adalah (1) melakukan dengan tenang dan terkendali, dan (2) menghindari gerakan-gerakan yang berlebihan. Intonasi baca dilakukan dengan cara (1) membaca dengan keras kata-kata tertentu, (2) membaca dengan lambat katakata tertentu, dan (3) membaca dengan nada tinggi kata-kata tertentu.

Ciri khas dari bentuk dan gaya baca puisi seacra deklamatoris adalah lepasnya teks puisi dari pembaca. Jadi, sebelum mendeklamasikan puisi, teks puisi harus dihapalkan. Bentuk dan gaya baca puisi ini dapat dilakukan dengan posisi (1) berdiri, (2) duduk, dan (3) berdiri, duduk, dan bergerak.

Jika deklamator memilih bentuk dan gaya baca dengan posisi berdiri, maka pesan puisi disampaikan melalui (1) gerakangerakan tangan: mengepal, menunjuk, mengangkat kedua tangan, (2) gerakangerakan kepala: melihat ke bawah, atas, samping kanan, samping kiri, serong, (3) gerakan-gerakan mata: membelalak, meredup, memejam, (4) gerakan-gerakan bibir: tersenyumm, mengatup, melongo, (5) gerakan-gerakan tangan, bahu, badan, dan raut muka dilakukan dengan total. Intonasi baca dilakukan dengan cara (1) membaca dengan keras kata-kata tertentu, (2) membaca dengan lambat kata-kata tertentu, (3) membaca dengan nada tinggi kata-kata tertentu.
Jika deklamator memilih bentuk dan gaya dengan posisi duduk, berdiri, dan bergerak, maka yang dilakukan pada posisi duduk adalah (1) memilih posisi duduk dengan santai, kaki agak ditekuk, posisi miring dan badan agak membungkuk, Dan (2) arah dan pandangan mata dilakukan bervariasi: menatap dan menunduk. Sedang yang dilakukan pada posisi berdiri (1) mengambil sikap tegak dengan wajah menengadah, tangan menunjuk, dan (2) wajah berseri-seri dan bibir tersenyum. Yang dilakukan pada saat bergerak (1) melakukan dengan tenang dan bertenaga, dan (2) kaki dilangkahkan dengan pelan dan tidak tergesagesa. Intonasi dilakukan dengan cara (1) membaca dengan keras kata-kata tertentu, (2) membaca dengan lambat kata-kata tertentu, dan (3) membaca dengan nada tinggi katakata tertentu.

Ciri khas bentuk dan gaya baca puisi teaterikal bertumpu pada totalitas ekspresi, pemakaian unsur pendukung, misal kostum, properti, setting, musik, dll., meskipun masih terikat oleh teks puisi/tidak. Bentuk dan gaya baca puisi secara teaterikal lebih rumit daripada poetry reading maupun deklamatoris. Puisi yang sederhana apabila dibawakan dengan ekspresi akan sangat memesona.

Senada dengan hal tersebut, menurut Raminah Baribin dalam Suliyanto (2009:910) bahwa cara membaca untuk mengapresiasi puisi (geguritan) diantaranya dapat dilakukan dengan cara Exhibition Teaching Learning, dimana dalam pembelajaran peserta didik diharapkan tampil (exhibition) dan adu keterampilan/kompetisi (champion).

Wujud dari penampilan (exhibition) tersebut di antaranya dapat diaktualisasikan dengan gaya baca teatrikal. Teatrikalisasi mampunyai makna pementasan suatu karya yang mengutamakan gerak-gerik, suara, tidak berunsur cerita yang bersifat alur, tetapi memperlihatkan nuansa suasana yang mengarah kepada suatu gambaran samar yang dapat diberi makna oleh penonton.

Bertolak dari penjelasan di atas, maka metode teatrikalisasi dapat dipergunakan untuk mendorong peserta didik agar dapat menyelidiki membaca geguritan dengan 
mengaktualisasikan bahasa puisi dalam gerakan-gerakan pentas. Metode ini identik dengan pendekatan laboratoris dan belajar bebas.

Membaca geguritan dengan metode teatrikalisasi adalah cara membaca geguritan dengan mengaktualisasikan bahasa puisi dalam gerakan-gerakan pentas. Aktualisasi tersebut dengan memperhatikan isi, tempo, nada, dinamik, ekspresi dalam geguritan.

Motivasi menurut Anton $\mathrm{M}$. Moeliono (2000:756) adalah dorongan yang timbul pada diri seseorang secara sadar atau tidak sadar untuk melakukan tindakan dengan tujuan tertentu. Motivasi membaca geguritan adalah dorongan yang timbul pada diri peserta didik untuk membaca geguritan dengan teknik dan pemahaman yang benar.

Berdasarkan kerangka berpikir tersebut, peneliti berasumsi bahwa: 1) pemanfaatan metode pembelajaran teatrikalisasi geguritan untuk aspek membaca geguritan diduga meningkatkan aktivitas belajar peserta didik, 2) metode pembelajaran teatrikalisasi geguritan diduga efektif untuk merubah motivasi belajar peserta dalam pembelajaran membaca geguritan, dan 3) pemanfaatan metode teatrikalisasi geguritan diduga efektif meningkatkan keterampilan membaca geguritan peserta didik Kelas $6 \mathrm{SD}$ 1 Sadang Kecamatan Jekulo Kabupaten Kudus semester 1 tahun pelajaran 2014/1015.

\section{METODE PENELITIAN}

Penelitian dengan judul Upaya Peningkatan Keterampilan dan Motivasi Membaca Geguritan melalui Metode Teatrikalisasi Geguritan ini, dilakukan pada peserta didik kelas 6 Semester 1Tahun Pelajaran 2014/2015 SD 1 Sadang Kecamatan Jekulo Kabupaten Kudus.

Penelitian ini dilakukan sejak bulan Juli 2014 sampai dengan Oktober 2014. Dengan rincian sebagai berikut: pada bulan Juli 2014 prasiklus, bulan Agustus pertengahan siklus 1, dan siklus 2 pada bulan September. Sedangkan bulan Oktober 2014 minggu kedua penyusunan laporan.

Subjek penelitian tindakan ini adalah guru mata pelajaran bahasa Jawa dan peserta didik kelas 6 Semester 1Tahun Pelajaran
2014/2015 SD 1 Sadang Kecamatan Jekulo Kabupaten Kudus.

Penelitian ini bersifat kolaborator. Guru mata pelajaran bahasa jawa sebagai peneliti dan seorang guru kelas 6 yang bernama Sunarti, S.Pd.SD. sebagai kolaborator. peserta didik kelas 6 Semester 1 Tahun Pelajaran 2014/2015 SD Negeri 1 Sadang Kecamatan Jekulo Kabupaten Kudus berjumlah 32 orang siswa. Dari 32 siswa berjenis kelamin perempuan sebanyak 16 siswa, dan laki-laki sebanyak 16 Siswa. Pekerjaan orang tua $25 \%$ pegawai negeri, 25 $\%$ swasta, dan $50 \%$ petani. Sedangkan tingkat kecerdasan dan pengetahuan dasar sedang, karena termasuk kelas nonunggulan. Penguasaan Keterampilan membaca geguritan masih rendah. Hanya $10 \%$ siswa yang memiliki keterampilan membaca geguritan sedang.

Adapun yang menjadi objek penelitian adalah pembelajaran keterampilan membaca geguritan berbasis lingkungan belajar sekitar siswa.

Dalam menjawab permasalahan, ada beberapa faktor yang akan diselidiki, yaitu: 1) peserta didik, memperhatikan minat, motivasi, keberanian, partisipasi, dan hasil pembelajaran, 2) pembelajaran, mengamati efektivitas penggunaan metode teatrikalisasi geguritan dalam meningkatkan keterampilan membaca geguritan peserta didik kelas 6 Semester 1 Tahun Pelajaran 2014/2015 SD 1 Sadang Kecamatan Jekulo Kabupaten Kudus.

Penelitian tindakan kelas ini mengacu model penelitian yang dikembangkan Kemmis dan Taggart (dalam Aqib, 2006: 22). Rencana tindakan dalam penelitian ini terdiri dari 3 siklus. Masing-masing siklus adalah saling berkaitan.

Adapun gambaran pelaksanaan siklus adalah sebagai berikut:1) perencanaan (plan), 2) pelaksanaan dan pengamatan (action dan observasi), 3. Refleksi,guru merefleksikan proses pembelajaran dengan pengamat, menyimpulkan dan menilai hasil kerja peserta didik pada siklus 1, dalam siklus pertama apabila dirasa masih kurang maksimal maka akan dilanjutkan pada siklus 2, pelaksanaan siklus 2 tetap melalui tiga tahapan yaitu perencanaan, pelaksanaan dan observasi, dan refleksi, jika hasil masih juga belum 
memuaskan maka dilaksankan siklus 3 dengan tahapan yang sama.

Model tersebut menyebutkan bahwa penelitian tindakan kelas menggunakan beberapa siklus. Setiap siklus terdiri dari empat langkah, yaitu

1. perencanaan (Planning)

2. Tindakan (acting)

3. Observasi (observing)

4. Refleksi (reflecting)

Sesudah sesuatu siklus selesai diimplementasikan, khususnya sesudah adanya refleksi, kemudian diikuti dengan adanya perencanaan ulang (replanning) tau revisi terhadap implementasi siklus sebelumnya. Selanjutnya, berdasarkan perencanaan ulang tersebut dilaksanakan dalam bentuk siklus tersendiri. Demikian untuk seterusnya, satu siklus diikuti dengan siklus berikutnya.

Pada penelitian tindakan kelas ini peneliti menggunakan 2 siklus yang berkelanjutan yaitu proses tindakan pada siklus I dan siklus II. Penelitian ini bertujuan untuk memperbaiki pelaksanaan pembelajaran. Siklus ini terdiri dari empat komponen, yaitu perencanaan, tindakan, pengamatan atau observasi, dan refleksi. Keempat komponen tersebut dipandang sebagai siklus. Jika tindakan pada siklus I nilai rata-ratanya belum mencapai target yang telah ditentukan, akan diperbaiki pada siklus II. Keempat komponen tersebut yaitu : perencanaan, tindakan, observasi dan refleksi.

Variabel dalam penelitian ini ada 2, yaitu variable input dan output. Variabel inputoutput pada penelitian ini adalah keterampilan dan motivasi membaca geguritan. Tindakan yang akan dilakukan pada pembelajaran membaca geguritan yaitu guru membagikan teks geguritan pada siswa. Setelah itu guru memberikan soal apersepsi pada siswa, dan guru mencatat siswa yang mengalami kesulitan dalam membaca geguritan. Target yang diharapkan adalah dengan metode Teatrikalisasi geguritan, keterampilan motivasi membaca geguritan siswa dapat bertambah.

Variabel proses adalah pembelajaran membaca geguritan dengan metode teatrikalisasi geguritan. Dalam metode tersebut menekankan siswa latihan secara aktif, namun bersifat sederhana, sehingga diharapkan mampu meningkatkan keterampilan membaca geguritan.

Menurut Zuriah (2003), ada 5 jenis instrumen yang digunakan dalam penelitian tindakan. Diantaranya observasi, wawancara, catatan lapangan, angket, dan dokumentasi. Dalam penelitian ini instrumen yang digunakan meliputi: (1) observasi, (2) wawancara, dan (3) dokumentasi.

Obserasi diartikan sebagai pengamatan dan pencatatan secara sistematik terhadap gejala yang tampak pada objek penelitian (Zuriah, 2003). Ada dua jenis observasi yang dilakukan, diantaranya: (a) observasi langsung, yaitu observasi yang dilakukan dimana observer berada bersama objek yang diselidiki, dan (b) obsevasi tidak langsung, yaitu observasi atau pengamatan yang dilakukan tidak pada saat berlangsungnya suatu peristiwa yang akan diteliti. Dengan menggunakan teknik ini, melakukan catatan terhadap hasil observasi dengan menggunakan daftar cek (chek list).

Dalam penelitian yang dilakukan secara kolaboratif yang melibatkan guru mata pelajaran bahasa Jawa yang berfungsi sebagai pengamat di kelas ini menggunakan instrumen sebagai berikut : 1) lembar wawancara untuk mengetahui minat peserta didik, 2) lembar observasi untuk peserta didik, untuk memonitor proses, 3) lembar observasi untuk guru, 4) lembar evaluasi/penilaian.

Instrumen penelitian yang digunakan untuk mengumpulkan data dalam penelitian ini berupa tes dan non tes. Tes yang digunakan untuk mengumpulkan data tentang kesulitan membaca geguritan berupa tes membaca geguritan.

Penelitian diawali dengan pelaksanaan tes awal atau pretes untuk mengetahui pengetahuan dan kemampuan siswa membaca geguritan. Setelah proses pembelajaran, diadakan tes membaca geguritan. Tes ini dilaksanakan untuk mengetahui ketepatan teknik siswa baik nada, tempo, dinamik, ekspresi siswa dalam membaca geguritan setelah mengikuti proses pembelajaran.

Tes yang digunakan untuk mengukur keterampilan membaca geguritan siswa 
berupa teks geguritan yang telah disiapkan oleh peneliti. Tingkat kesulitan dijadiakan pedoman untuk memperbaiki strategi pembelajaran berikutnya.

Teknik dan alat pengumpulan data dalam penelitian tindakan kelas ini meliputi: observasi, wawancara, angket, tes dan studi dokumentasi.

Agar data valid dan reliabel, selama pengumpulan data dilakukan validasi data. Teknis analisis data dalam penelitian ini, adalah analisis deskriptif. Analisis dilakukan dari hasil angket, observasi, tugas, dan hasil belajar. Analisis dilakukan tahap demi tahap atau dari siklus 1 hasilnya direfleksikan ke siklus 2.

Dalam penelitian tindakan kelas ini, analisis data meliputi tiga langkah pokok, yaitu: (1) reduksi data; (2) penyajian data; dan (3) penarikan kesimpulan dan verifikasi.

Reduksi data, penyajian data, dan penarikan kesimpulan sebagai sesuatu yang jalin menjalin pada saat sebelum, selama dan sesudah pengumpulan data dalam bentuk yang sejajar untuk membangun wawasan umum yang disebut analisis.

Penelitian upaya peningkatan keterampilan membaca geguritan dengan metode teatrikalisasi geguritan peserta didik kelas 6 SD 1 Sadang Jekulo Kudus semester 1 tahun pelajaran 2014/2015 ini dinyatakan berhasil dengan indikator: 1) terjadi peningkatan hasil belajar secara keseluruhan keterampilan membaca geguritan peserta didik memenuhi target nilai $75 \%$ dalam ratarata kelas sesuai dengan KKM nilai Bahasa Jawa 70,2) terjadi motivasi yang tinggi yaitu 90\% dalam mengikuti pelajaran bahasa Jawa, 3) terjadinya aktivitas yang tinggi yaitu $90 \%$ dalam belajar bahasa Jawa.

\section{HASIL PENELITIAN DAN PEMBAHASANNYA}

Penelitian ini dilaksanakan dengan tiga kali tindakan siklus, yaitu prasiklus, siklus I dan siklus II. Sebelum dimulai tindakan siklus 1, diadakan apersepsi mata pelajaran bahasa Jawa pokok bahasan membaca geguritan. Kegiatan pra siklus dilaksanakan hari Kamis tanggal 24 Juli 2014. Hasil pembelajaran pada prasiklus yang berupa data tes dikelompokkan dalam distribusi frekuensi sebgai berikut :

Tabel 4.1 Hasil Nilai Keterampilan Membaca geguritan Prasiklus

\begin{tabular}{cccc}
\hline No & Kategori & $\begin{array}{c}\text { Nilai keterampilan } \\
\text { membaca geguritan }\end{array}$ & Frekuensi \\
\hline 1. & Sangat baik & $90-100$ & - \\
2. & Baik & $80-89$ & - \\
3. & Cukup & $70-79$ & 4 \\
4. & Kurang & $40-69$ & 25 \\
5. & Sangat Kurang & $0-39$ & 3 \\
\hline \multicolumn{5}{c}{ Jumlah } & & 32 \\
\hline & Hasil tes & prasiklus, siswa & yang
\end{tabular}

memperoleh nilai keterampilan membaca geguritan untuk kategori sangat baik yaitu rentang nilai keterampilan membaca geguritan 90 - 100 tidak dicapai oleh siswa. Kategori baik yaitu dengan rentang nilai keterampilan membaca geguritan 80-89 tidak dicapai oleh siswa. Kategori cukup dengan rentang nilai keterampilan membaca geguritan 70-79 dicapai oleh 4 siswa. Kategori kurang dengan rentang nilai keterampilan membaca geguritan 40-69 dicapai 25 siswa. Sedangkan untuk kategori sangat kurang dengan rentang nilai keterampilan membaca geguritan 0-39 dicapai 3 siswa. Jadi rata-rata keterampilan membaca geguritan peserta didik kelas 6 Semester 1 Tahun Pelajaran 2014/2015 SD 1 Sadang Kecamatan Jekulo Kabupaten Kudus yang pembelajarannya menggunakan materi metode teatrikalisasi geguritan sebesar $12.5 \%$ dengan kategori cukup dan memenuhi KKM, serta $78.1 \%$ kurang, dan $9.4 \%$ sangat kurang. Dengan demikian secara keseluruhan keterampilan membaca geguritan siswa belum memenuhi target nilai $75 \%$ dalam rata-rata kelas sesuai dengan KKM nilai Bahasa Jawa 70. Hasil non tes dapat diperoleh dari obserwasi, wawancara, dan jurnal. Hasil non tes digunakan untuk mengetahui minat, keberanian, serta aktivitas peserta didik dalam membaca geguritan.

Adapun minat, keberanian, serta aktivitas peserta didik dalam membaca geguritan pada kegiatan prasiklus dapat dilihat pada tabel sebagai berikut: 


\begin{tabular}{ccccl}
\hline $\begin{array}{c}\text { No } \\
\cdot\end{array}$ & Pernyataan & Jumlah & $\begin{array}{c}\text { Prosentas } \\
\text { e }\end{array}$ & Keterangan \\
\cline { 1 - 3 } 1 & Berminat & 10 & $31,25 \%$ & \\
\cline { 1 - 3 } & Tidak berminat & 22 & $68,75 \%$ & $\begin{array}{l}\text { Data diperoleh } \\
\text { dari observasi, } \\
\text { wawancara, dan } \\
\text { jurnal }\end{array}$ \\
\cline { 1 - 2 } & Berani & 8 & $26,67 \%$ & \\
\hline 4 & Tidak berani & 24 & $73,33 \%$ & \\
\hline
\end{tabular}

Aktivitas peserta didik yang diamati dalam penelitian ini adalah aktivitas dalam kelas. Berdasarkan pada observasi dan catatan peneliti dalam penelitian tindakan ini, diperoleh data aktivitas peserta didik prasiklus sebagai berikut.

Tabel 4.3 Prosentase Pengelompokan Aktivitas peserta didik kelas 6 Semester 1 Tahun Pelajaran 2014/2015 SD 1 Sadang Kecamatan Jekulo Kabupaten Kudus dalam Membaca geguritan.

\begin{tabular}{ccc}
\hline Tingkatan & Frekuensi & Prosentase \\
\hline Tinggi & 5 & $15.63 \%$ \\
\hline Sedang & 17 & $53.13 \%$ \\
\hline Kurang & 10 & $31.24 \%$
\end{tabular}

Berdasarkan tabel tersebut, keaktifan peserta didik dalam mengikuti kegiatan belajar mengajar terlihat bahwa dari 32 peserta didik, 5 peserta didik $(15,63 \%)$ memiliki aktivitas yang tinggi, 10 peserta didik (31,24\%) aktivitasnya kurang, sedangkan sebagian besar yaitu 17 peserta didik $(53,13 \%)$ peserta didik keaktifannya sedang.

Siklus I dipersiapkan pada minggu ketiga bulan Juli, kemudian dilaksanakan pada hari Kamis 21 Agustus 2014. Hasil tes pada tindakan pembelajaran siklus I secara lengkap (terlampir) dan secara ringkas disajikan dalam bentuk tabel berikut:

Tabel 4.4 Hasil Nilai Keterampilan Membaca geguritan Siklus I

\begin{tabular}{cccc}
\hline No & Kategori & $\begin{array}{c}\text { Nilai keterampilan } \\
\text { membaca geguritan }\end{array}$ & Frekuensi \\
1. & Sangat baik & $90-100$ & - \\
2. & Baik & $80-89$ & 6 \\
3. & Cukup & $70-79$ & 15 \\
4. & Kurang & $40-69$ & 11 \\
5. & Sangat kurang & $0-39$ & - \\
& Jumlah & & 32 \\
\hline & Hasil tes siklus I, siswa yang
\end{tabular}

memperoleh nilai keterampilan membaca geguritan untuk kategori sangat baik yaitu rentang nilai keterampilan membaca geguritan 90 - 100 tidak dicapai oleh siswa. Kategori baik yaitu dengan rentang 80-89 dicapai oleh
6 siswa. Kategori cukup dengan rentang nilai keterampilan membaca geguritan 70-79 dicapai oleh 15 siswa. Kategori kurang dengan rentang nilai keterampilan membaca geguritan 40-69 dicapai 11 siswa. Sedangkan untuk kategori sangat kurang dengan rentang nilai 0-39 tidak dicapai oleh siswa. Jadi ratarata keterampilan membaca geguritan peserta didik kelas 6 Semester 1 Tahun Pelajaran 2014/2015 SD 1 Sadang Kecamatan Jekulo Kabupaten Kudus yang pembelajarannya menggunakan materi metode teatrikalisasi geguritan sebesar $18.8 \%$ dengan kategori baik dan memenuhi KKM, serta $46.9 \%$ cukup, dan $34.3 \%$ kurang. Dengan demikian secara keseluruhan keterampilan membaca geguritan siswa baru mencapai $65.7 \%$, belum memenuhi target nilai $75 \%$ dalam rata-rata kelas sesuai dengan KKM nilai Bahasa Jawa 70.

Minat, keberanian, dan aktivitas peserta didik dalam membaca geguritan berbahasa Jawa adalah sebagai berikut:

\begin{tabular}{|c|c|c|c|c|}
\hline No & Pernyataan & Jumlah & Prosentase & Ket. \\
\hline 1 & Berminat & 21 & $65,63 \%$ & \multirow{4}{*}{$\begin{array}{l}\text { Data } \\
\text { diperoleh } \\
\text { dari } \\
\text { observasi, } \\
\text { wawancar } \\
\text { a, jurnal }\end{array}$} \\
\hline 2 & Tidak berminat & 11 & $34,37 \%$ & \\
\hline 3 & Berani & 19 & $59,38 \%$ & \\
\hline 4 & Tidak berani & 13 & $40,62 \%$ & \\
\hline
\end{tabular}

Dari tabel tersebut, membuktikan bahwa 21 peserta $\operatorname{didik}(65,63 \%)$ berminat, 11 peserta didik $(34,37 \%)$ tidak berminat, 19 peserta didik $(59,38 \%)$ berani, 13 peserta didik $(40,62 \%)$ tidak berani. Dengan demikian, pelaksanaan siklus I, minat dan keberanian peserta didik peserta didik kelas 6 Semester 1 Tahun Pelajaran 2014/2015 SD 1 Sadang Kecamatan Jekulo Kabupaten Kudus mengalami peningkatan dalam membaca geguritan.

Aktivitas peserta didik yang diamati dalam penelitian ini adalah aktivitas dalam kelas. Berdasarkan pada observasi dan catatan peneliti dalam penelitian tindakan ini, diperoleh data aktivitas peserta didik pada siklus I sebagai berikut. 
Tabel 4.6 Prosentase Pengelompokan Aktivitas peserta didik kelas 6 Semester 1 Tahun Pelajaran 2014/2015 SD 1 Sadang Kecamatan Jekulo Kabupaten Kudus dalam Membaca geguritan

\begin{tabular}{ccc}
\hline Tingkatan & Frekuensi & Prosentase \\
\hline Tinggi & 12 & $37.50 \%$ \\
\hline Sedang & 15 & $46.88 \%$ \\
\hline Kurang & 5 & $15.62 \%$
\end{tabular}

Berdasarkan tabel tersebut, keaktifan peserta didik dalam mengikuti kegiatan belajar mengajar terlihat bahwa dari 32 peserta didik, 12 peserta didik $(37,50 \%)$ memiliki aktivitas yang tinggi, 15 peserta didik (46,88\%) aktivitasnya sedang, sedangkan 5 peserta didik $(15,62 \%)$ peserta didik keaktifannya kurang.

Kegiatan siklus II dilaksanakan pada hari Kamis 25 September 2014. Hasil tes pada tindakan pembelajaran siklus II secara lengkap (terlampir) dan secara ringkas disajikan dalam bentuk tabel berikut:

Tabel 4.7 Hasil Nilai Keterampilan Membaca geguritan Siklus II.

\begin{tabular}{cccc}
\hline No & Kategori & $\begin{array}{c}\text { Nilai keterampilan } \\
\text { membaca geguritan }\end{array}$ & Frekuensi \\
\hline 1. & Sangat baik & $90-100$ & 7 \\
2. & Baik & $80-89$ & 8 \\
3. & Cukup & $70-79$ & 15 \\
4. & Kurang & $40-69$ & 2 \\
5. & Sangat Kurang & $0-39$ & - \\
\hline & Jumlah & & 32 \\
\hline
\end{tabular}

Hasil tes siklus II, siswa yang memperoleh jumlah kata untuk kategori sangat baik yaitu rentang nilai keterampilan membaca geguritan 90-100 dicapai oleh 7 siswa. Kategori baik yaitu dengan rentang nilai keterampilan membaca geguritan 80-89 dicapai oleh 8 siswa. Kategori cukup dengan rentang nilai keterampilan membaca geguritan 70-79 dicapai oleh 15 siswa. Kategori kurang dengan rentang nilai keterampilan membaca geguritan 40-69 dicapai oleh 2 siswa. Sedangkan untuk kategori sangat kurang dengan rentang nilai keterampilan membaca geguritan 0-39 tidak dicapai oleh siswa. Jadi rata-rata keterampilan membaca geguritan peserta didik kelas 6 Semester 1 Tahun Pelajaran 2014/2015 SD 1 Sadang Kecamatan Jekulo Kabupaten Kudus yang pembelajarannya menggunakan materi metode teatrikalisasi geguritan sebesar 21.9\% dengan kategori sangat baik dan memenuhi KKM, serta $25 \%$ baik, dan $46.9 \%$ cukup, dan $6.2 \%$ kurang. Dengan demikian secara keseluruhan keterampilan membaca geguritan siswa mencapai $93.8 \%$, sudah melampaui target nilai $75 \%$ dalam rata-rata kelas sesuai dengan KKM nilai Bahasa Jawa 70. Adapun nilai keterampilan membaca geguritan tersebut berasal dari rata-rata nilai keterampilan yang meliputi nada, tempo, dinamik, dan ekspresi dalam membaca geguritan.

Minat, keberanian, dan aktivitas peserta didik dalam membaca geguritan berbahasa Jawa pada siklus II adalah sebagai berikut:

Tabel 4.8

Minat Dan Keberanian Membaca Geguritan

\begin{tabular}{ccccl}
\hline No & Pernyataan & Jumlah & Prosentase & Keterangan \\
\cline { 1 - 3 } 1 & Berminat & 30 & $93,75 \%$ & $\begin{array}{l}\text { Data } \\
\text { diperoleh } \\
\text { dari } \\
\text { observasi, } \\
\text { wawancara, } \\
\text { jurnal }\end{array}$ \\
\hline 3 & Tidak berminat & 2 & $6,25 \%$ & $90,63 \%$ \\
\hline
\end{tabular}

Dari tabel tersebut, membuktikan bahwa 30 peserta didik $(93,75 \%)$ berminat, 2 peserta didik $(6,25 \%)$ tidak berminat, 29 peserta didik $(90,63 \%)$ berani, 3 peserta didik $(9,37 \%)$ tidak berani. Dengan demikian, pelaksanaan siklus II, minat dan keberanian peserta didik kelas 6 Semester 1 Tahun Pelajaran 2014/2015 SD 1 Sadang Kecamatan Jekulo Kabupaten Kudus mengalami peningkatan dan sudah mencapai target yang diharapkan (90\% atau lebih).

Aktivitas peserta didik yang diamati dalam penelitian ini adalah aktivitas dalam kelas. Berdasarkan pada observasi dan catatan peneliti dalam penelitian tindakan ini, diperoleh data aktivitas peserta didik pada siklus II sebagai berikut: 
Tabel 4.9 Prosentase Pengelompokan Aktivitas peserta didik kelas 6 Semester 1 Tahun Pelajaran 2014/2015 SD 1 Sadang Kecamatan Jekulo kabupaten Kudus dalam Membaca geguritan. Tingkatan Frekuensi Prosentase

\begin{tabular}{ccc}
\hline Tinggi & 29 & $90,63 \%$ \\
\hline Sedang & 2 & $6,25 \%$ \\
\hline Kurang & 1 & $3,12 \%$ \\
\hline
\end{tabular}

Berdasarkan tabel tersebut, keaktifan peserta didik dalam mengikuti kegiatan belajar mengajar terlihat bahwa dari 32 peserta didik, 29 peserta didik (90,63\%) memiliki aktivitas yang tinggi, 2 peserta didik $(6,25 \%)$ aktivitasnya sedang, sedangkan 1 peserta didik $(3,12 \%)$ peserta didik keaktifannya kurang.

Setelah dilakukan refleksi kegiatan pembelajaran siklus II, maka dapat disimpulkan bahwa upaya untuk meningkatkan keterampilan dan motivasi peserta didik dalam membaca geguritan dengan menggunakan metode tetatrikalisasi geguritan pada peserta didik kelas 6 Semester 1 Tahun Pelajaran 2014/2015 SD 1 Sadang Kecamatan Jekulo Kabupaten Kudus menunjukkan hasil yang signifikan. Dengan demikian, hipotesis ketiga diterima, pemanfaatan metode teatrikalisasi geguritan diduga efektif meningkatkan keterampilan membaca geguritan peserta didik kelas 6 Semester 1 Tahun Pelajaran 2014/2015 SD 1 Sadang Kecamatan Jekulo Kabupaten Kudus.

Pembelajaran membaca geguritan sangat penting. Sesuai tuntutan kurikulum, anak didik harus belajar membaca geguritan secara optimal (Mulyono, 2009:2). Namun, dengan menggunakan metode teatrikalisasi geguritan, ternyata aktivitas peserta didik dapat didorong dan dipacu sehingga proses pembelajaran menjadi aktif. Hal tersebut dapat dilihat dari perkembangan aktivitas peserta didik pada pelaksanaan pembelajaran prasiklus, siklus I dan siklus II seperti berikut;
Tabel 4.10 Rekapitulasi Aktivitas peserta didik kelas 6 Semester 1 Tahun Pelajaran 2014/2015 SD 1 Sadang Kecamatan Jekulo Kabupaten Kudus dalam KBM Membaca Geguritan.

\begin{tabular}{cccccccc}
\hline \multirow{2}{*}{ No } & \multirow{2}{*}{ Tingkatan } & \multicolumn{2}{c}{$\begin{array}{c}\text { Sebelum } \\
\text { Penelitian }\end{array}$} & \multicolumn{2}{c}{ Siklus 1 } & \multicolumn{2}{c}{ Siklus 2 } \\
\cline { 3 - 7 } & & Jml & Prosen & Jml & Prosen & Jml & Prosen \\
\hline \multirow{2}{*}{1} & Tinggi & 5 & $15.63 \%$ & 12 & $37.50 \%$ & 29 & $90,63 \%$ \\
\hline 2 & Sedang & 17 & $53.13 \%$ & 15 & $46.88 \%$ & 2 & $6,25 \%$ \\
\hline 3 & Kurang & 5 & $16,66 \%$ & 5 & $15.62 \%$ & 1 & $3,12 \%$ \\
\hline
\end{tabular}

Dari hasil rekapitulasi aktivitas peserta didik tersebut, maka hipotesis pertama diterima, yaitu pemanfaatan metode pembelajaran teatrikalisasi geguritan untuk aspek membaca geguritan dapat meningkatkan aktivitas belajar peserta didik kelas 6 Semester 1 Tahun Pelajaran 2014/2015 SD 1 Sadang Kecamatan Jekulo Kabupaten Kudus.

Perubahan motivasi belajar peserta didik pada pembelajaran membaca geguritan menunjukkan bahwa motivasi belajar peserta didik setiap siklus mengalami perubahan yang lebih baik dan mengarah pada motivasi yang positif. Hal tersebut dapat dilihat dari hasil rekapitulasi perkembangan minat dan keberanian membaca geguritan dengan menggunakan metode teatrikalisasi geguritan prasiklus, siklus I, dan siklus II.

Tabel 4.11 Rekapitulasi Minat dan Keberanian Membaca Geguritan peserta didik kelas 6 Semester 1 Tahun Pelajaran 2014/2015 SD 1 Sadang Kecamatan Jekulo Kabupaten Kudus

\begin{tabular}{cccccccc}
\hline \multirow{2}{*}{$\begin{array}{c}\text { No } \\
\cdot\end{array}$} & Pernyataan & \multicolumn{2}{c}{$\begin{array}{c}\text { Sebelum } \\
\text { Penelitian }\end{array}$} & \multicolumn{2}{c}{ Siklus 1 } & \multicolumn{2}{c}{ Siklus 2 } \\
\cline { 3 - 7 } & & Jml & Prosen & Jml & Prosen & Jml & Prosen \\
\hline 1 & Berminat & 10 & $31,25 \%$ & 21 & $65,63 \%$ & 30 & $93,75 \%$ \\
\hline 2 & $\begin{array}{c}\text { Tidak } \\
\text { berminat }\end{array}$ & 22 & $68,75 \%$ & 11 & $34,37 \%$ & 2 & $6,25 \%$ \\
\hline \hline 3 & Berani & 8 & $26,67 \%$ & 19 & $59,38 \%$ & 29 & $90,63 \%$ \\
\hline 4 & $\begin{array}{c}\text { Tidak } \\
\text { berani }\end{array}$ & 22 & $73,33 \%$ & 14 & $46,67 \%$ & 3 & $9,37 \%$ \\
\hline
\end{tabular}

Dari hasil rekapitulasi minat dan

keberanian tersebut peserta didik tersebut, maka hipotesis pertama diterima, yaitu metode pembelajaran teatrikalisasi geguritan efektif untuk merubah motivasi belajar peserta didik kelas 6 Semester 1 Tahun 
Pelajaran 2014/2015 SD 1 Sadang Kecamatan Jekulo Kabupaten Kudus.

Tabel 4 Perbandingan Nilai Keterampilan Membaca geguritan.

\begin{tabular}{|c|c|c|c|c|c|}
\hline \multirow[b]{2}{*}{ No } & \multirow[b]{2}{*}{ Kategori } & \multirow{2}{*}{$\begin{array}{c}\text { Nilai } \\
\text { Keterampilan } \\
\text { Membaca } \\
\text { Geguritan } \\
\end{array}$} & \multicolumn{3}{|c|}{ Frekuensi } \\
\hline & & & $\begin{array}{c}\text { Pra } \\
\text { Siklus }\end{array}$ & $\begin{array}{c}\text { Siklus } \\
\text { I }\end{array}$ & Siklus II \\
\hline 1. & Sangat baik & $90-100$ & - & - & 7 \\
\hline 2. & Baik & $80-89$ & - & 6 & 8 \\
\hline 3. & Cukup & $70-79$ & 4 & 15 & 15 \\
\hline 4. & Kurang & $40-69$ & 25 & 11 & 2 \\
\hline 5. & Sangat Kurang & $0-39$ & 3 & - & - \\
\hline & Jumlah & & 32 & 32 & 32 \\
\hline
\end{tabular}

Pada siklus I mulai ada peningkatan yang signifikan dibandingkan pada prasiklus, pada siklus I ini sebagian besar siswa mulai menguasai membaca geguritan. Meskipun ada peningkatan akan tetapi hasil yang dicapai belum maksimal, hal ini disebabkan masih ada sedikit hambatan yang ditemui pada saat proses belajar mengajar, pada saat guru mengajar siswa sudah mau memperhatikan apa yang disampaikan guru, akan tetapi siswa kurang aktif dalam mengikuti pembelajaran sehingga penguasaan membaca geguritan belum dapat dicapai dengan maksimal.

Pada siklus II ini mengalami peningkatan yang tinggi karena hasil tersebut pada siklus I belum didapat dicapai. Hal ini membuktikan bahwa terjadi perbaikan sikap kearah yang lebih baik. Siswa-siswa tersebut rata-rata dapat memeragakan keterampilan membaca geguritan dengan baik. Mereka penuh antusias dan sungguh-sungguh dalam melakukan tes membaca geguritan. Selain itu mereka aktif dalam pembelajaran membaca geguritan dengan teatrikalisasi geguritan.

Pada proses pembelajaran siklus II telah ada peningkatan batas tuntas belajar, yakni ada 30 siswa yang memperoleh jumlah kata di atas batas ketuntasan yaitu memperoleh nilai $\geq 70$ sesuai dengan KKM Mata Pelajaran Bahasa Jawa pada peserta didik kelas 6 SD 1 Sadang Kecamatan Jekulo Kabupaten Kudus yang telah ditetapkan. Ini berarti batas tuntas telah terpenuhi karena jumlah siswa yang tuntas KKM mencapai 93.8\%. Dengan kata lain pembelajaran peningkatan kecepatan membaca geguritan dengan metode teatrikalisasi geguritan pada peserta didik kelas 6 Semester 1 Tahun Pelajaran 2014/2015 SD 1 Sadang Kecamatan
Jekulo Kabupaten Kudus telah memenuhi hipotesis yang diajukan. Hasil tersebut diketahui telah diadakan analisis hasil tes nilai keterampilan membaca geguritan pada siklus I dan siklus II.

Perubahan peningkatan minat dan keberanian pada pra siklus, siklus I, dan siklus II dalam membaca geguritan dengan menggunakan metode teatrikalisasi geguritan menunjukkan bahwa motivasi belajar siswa setiap siklus mengalami perubahan yang lebih baik dan mengarah pada motivasi yang positif. Pada pembelajaran membaca geguritan banyak memberikan pengalaman belajar yang baru bagi siswa sehingga wawasan dan pengetahuan mereka bisa bertambah.

\section{PENUTUP}

Simpulan hasil penelitian ini: 1) proses pembelajaran dengan menerapkan metode teatrikalisasi geguritan dapat meningkatkan aktivitas belajar peserta didik dalam belajar membaca geguritan peserta didik kelas 6 Semester 1 Tahun Pelajaran 2014/2015 SD 1 Sadang Kecamatan Jekulo Kabupaten Kudus, 2) metode teatrikalisasi geguritan dapat meningkatkan keterampilan membaca geguritan peserta didik kelas 6 Semester 1 Tahun Pelajaran 2014/2015 SD 1 Sadang Kecamatan Jekulo Kabupaten Kudus, dan 3) metode teatrikalisasi geguritan dapat meningkatkan motivasi belajar peserta didik yang kurang semangat menjadi semangat, kurang aktif menjadi aktif, kurang kreatif menjadi kreatif, kurang disiplin menjadi disiplin. Selain itu juga dapat menanamkan nilai-nilai pendidikan karakter kerja sama, komunikatif, dan rasa percaya diri.

\section{SARAN}

Untuk mengintensifkan metode teatrikalisasi geguritan, dapat disarankan sebagai berikut: 1) Kepada Kepala Sekolah supaya lebih banyak memberikan motivasi kepada guru dalam kegiatan belajar dan mengajar agar memanfaatkan metode yang bervariasi, khususnya metode teatrikalisasi geguritan, 2) Kepada Guru supaya meningkatkan kemampuannya dalam kegiatan pembelajaran dan mengembangkan kreativitasnya di antaranya dengan memanfaatkan metode 
teatrikalisasi geguritan agar dapat meningkatkan keterampilan dan motivasi membaca geguritan peserta didik, dan 3) Sekolah sebagai tempat dan penyelenggara pendidikan hendaknya melengakapi fasilitas dan kebutuhan peserta didik dalam kegiatan belajar dan mengajar.

\section{DAFTAR PUSTAKA}

Depdiknas. 2003. Standar Kompetensi Mata Pelajaran Bahasa Indonesia. Jakarta: Pusat Kurikulum, Balitbang Depdiknas

Mulyono, Sendang. 2009. Menafsirkan dan Membaca Geguritan. Semarang: Forum Kajian Budaya dan Media Bandungan Institute.

Saputra, Karsono.2001. Puisi Jawa ( Struktur dan estetika). Jakarta: wedatama widya sastra.

Suliyanto. 2009. Makalah: Bimbingan Teknis Mata Pelajaran Mulok Bahasa Jawa SMP. Semarang

Suwignyo (2005) dalam (http://endonesa.wordpress.com/lenterasastra/membacapuisi/) diunduh 12 Juli 2012.

Tarigan, Henry Guntur. 1994. Membaca Sebagai Suatu Keterampilan Berbahasa. Bandung : Angkasa.

Tim Pengembang Kurikulum. 2010. Kurikulum Mata Pelajaran Muatan Lokal (Bahasa Jawa) untuk Jenjang Pendidikan $S D / S D L B / M I$, SMP/SMPLB/MTs, Negeri dan Swasta Provinsi Jawa Tengah. Semarang : Kanwil Depdiknas Jawa Tengah.

Zainal Aqib. 2006. Penelitian Tindakan Kelas: untuk guru. Bandung: CV. Yrama Widya
Zuriah, N., 2003. Penelitian Tindakan dalam Bidang Pendidikan dan Sosial. Edisi Pertama. Malang: Bayu Media Publishing. 